Indonesian Journal of Pharmaceutical Science and Technology Journal Homepage : http://jurnal.unpad.ac.id/ijpst/

\title{
Isolation and Activity Assay of Secondary Metabolites of Aspergillus niger in-Habiting in Termite's Queen Nest Macrotermes gilvus Hagen. on Enriched Media
}

\author{
Yohannes Alen*, Evi Guslianti, Netty Suharti \\ Fakultas Farmasi, Universitas Andalas, Sumatera Barat - Indonesia
}

\author{
Submitted 2 February 2018; Revised 8 May 2018; Accepted 11 May 2018; Published 11 February 2018 \\ *Corresponding author: yohannesalen@yahoo.co.id
}

\begin{abstract}
The Fungus is a group of the microorganisms that produce secondary metabolites and may be changed in different media. Secondary metabolites from Aspergillus niger in habiting in termite's queen nest Macrotermes gilvus Hagen are disappeared gradually in artificial media. It was the reason to enrich the media with termite's queen nest. The purpose of this research was to obtain the similar secondary metabolites of $A$. niger as it grows in their habitat. Enrichment was done with the experimental method. It used three concentrations of nest $0.25 ; 0.75$ and $1 \mathrm{~g} / \mathrm{mL}$ Sabouraud Dextrose Agar (SDA) media. Isolation was done by chromatography method. The antibiotic activities against Pseudomonas aeruginosa ATCC 27853 and Enterococcus faecalis ATCC 10541 were performed by the diffusion method. Results showed that enrichment of nest $1 \mathrm{~g} / \mathrm{mL}$ media gave the best growth of fungus and it obtain the similar secondary metabolites as it grows in their habitat. Three pure compounds, EG-13-312, EG-13-34-9, and EG-13-44-2 were obtained. Based on physicochemical data, all compounds were terpenoid class and one of them (EG-13-34-9) contain the phenolic group. All compounds have activity against $P$. aeruginosa ATCC 27853 and E. faecalis ATCC 10541 the bacteriostatic category.
\end{abstract}

Keywords: Aspergillus niger, diffusion method, enriched media, isolation, Macrotermes gilvus Hagen, Sabouraud Dextrose Agar (SDA).

\section{Isolasi dan Uji Aktivitas Metabolit Sekunder Aspergillus niger "In-Habiting" Sarang Ratu Termite Macrotermes gilvus Hagen., pada Media diperkaya}

\begin{abstract}
Abstrak
Jamur adalah kelompok mikroorganisme yang menghasilkan metabolit sekunder yang mungkin berubah pada media yang berbeda. Metabolit sekunder dari Aspergillus niger yang tinggal di sarang ratu termite Macrotermes gilvus Hagen, menghilang secara bertahap pada media buatan. Itulah alasan diperkayanya media dengan sarang ratu termite. Tujuan dari penelitian ini adalah untuk mendapatkan metabolit sekunder A. niger yang sama seperti yang dihasilkan ketika tumbuh di habitatnya. Pengayaan dilakukan dengan metode eksperimen menggunakan tiga konsentrasi sarang 0,$25 ; 0,75$ dan $1 \mathrm{~g} / \mathrm{mL}$ media Sabouraud Dextrose Agar (SDA). Isolasi dilakukan dengan metode kromatografi. Uji aktivitas terhadap Pseudomonas aeruginosa ATCC 27853 dan Enterococcus faecalis ATCC 10541 dilakukan dengan metode difusi. Hasil penelitian menunjukkan bahwa pengayaan dengan sarang $1 \mathrm{~g} /$ $\mathrm{mL}$ memberikan pertumbuhan jamur yang terbaik dan menghasilkan metabolit sekunder yang sama dengan yang dihasilkan ketika tumbuh di habitatnya. Tiga senyawa murni, EG-13-31-2, EG-13-349, dan EG-13-44-2 berhasil diperoleh. Berdasarkan data fisikokimia, semua senyawa merupakan terpenoid dan salah satunya (EG-13-34-9) mengandung fenolik. Semua senyawa memiliki aktivitas terhadap P. aeruginosa ATCC 27853 dan E. faecalis ATCC 10541 dengan kategori bakteriostatik.
\end{abstract}

Kata Kunci: Aspergillus niger, isolasi, Macrotermes gilvus Hagen, media diperkaya, metode difusi, Sabouraud Dextrose Agar (SDA). 


\section{Pendahuluan}

Termite adalah salah satu jenis serangga ordo Isoptera, sangat mudah dijumpai di berbagai tipe ekosistem seperti ekosistem hutan, pertanian, perkebunan dan juga ditemukan di ekosistem permukiman atau perkotaan. ${ }^{1,2,3}$ Ratu termite sudah lama dijadikan sebagai obat tradisional., ${ }^{4,5}$ Hal ini dikarenakan ratu termite mengandung protein total $43,55 \%$, karbohidrat total $23,44 \%$, lemak total $23,31 \%$, kadar abu dan kadar air 6,99\% dan 1,22\%7,8,9. Masyarakat di Nigeria memanfaatkan termite sebagai makanan karena mengandung crude protein dan fiber. ${ }^{10}$

Termite hidup didalam sarang yang dibuat oleh kasta pekerja menggunakan bahan tanah ${ }^{3}$, ada juga jenis termite yang menggunakan bahan untuk membangun sarang seperti: pasir kuarsa, pasir halus, tanah liat dan juga kayu. ${ }^{11,12}$ Tanah ini direkatkan dengan air liur oleh kasta pekerja ${ }^{1}$, air liur ini diduga penyebab tumbuhnya jamur pada sarang termite. ${ }^{2}$

Jamur Aspergillus niger hidup pada sarang termite dan diduga melakukan simbiosis dengan ratunya. Termite memanfaatkan jamur sebagai makanan untuk membantunya dalam mensintesa selulosa dan lignin. ${ }^{13}$ Ada beberapa jamur yang hidup pada sarang termite, contohnya Tricoderme viride, Mucor himeralis, Rhizopus nigricans, Aspergillus flavus, Alternaria sp, Penicylium verucosum and Fusarium sp pada sarang Reticulitermes lucifugus. ${ }^{14}$

Pada penelitian terdahulu telah berhasil dilakukan penapisan 4 jamur pada sarang ratu Macrotermes gilvus Hagen., yaitu $A$. niger, A. flavus, Mucor dan Cladosporium, yang masing-masingnya memiliki senyawa metabolit sekunder. ${ }^{15}$ Jamur $A$. niger merupakan salah satu jamur yang mengandung metabolit sekunder yang aktif sebagai antibiotik. Senyawa tersebut adalah AM12-22-01 yang aktif terhadap Pseudomonas aeruginosa ATCC 27835 (MIC 1000 ppm), Enterococcus faecalis ATCC 29212 (MIC 125 ppm), dan senyawa AM-12-60-01 terhadap Pseudomonas aeruginosa ATCC 27835 (MIC $500 \mathrm{ppm}$ ), dan Enterococcus faecalis ATCC 29212 (MIC 1000 ppm). ${ }^{16}$
Pada jamur A. flavus diketahui bahwa senyawa metabolit yang dihasilkan hanya terdapat pada biakan pertama dan kedua sementara untuk biakan selanjutnya tidak lagi ditemukan. ${ }^{17,18}$ Hal ini diduga juga terjadi pada $A$. niger. Hilangnya metabolit sekunder jamur ini merupakan pengaruh dari perbedaan media tumbuh, sehingga senyawa yang dihasilkan juga berbeda. ${ }^{19}$

Merujukpada pendekatan OSMAC(One strain many compound), yaitu suatu metode dengan merubah komposisi media, kultivasi dan penambahan enzim dapat mempengaruhi senyawa metabolit yang dihasilkan ${ }^{20,21}$, seperti pada jamur Streptomyces sp, yang menghasilkan ${ }^{14}$ senyawa lebih banyak ketika media tumbuhnya diperkaya menggunakan $\mathrm{CaCO}_{3}$ dan $\mathrm{Al}_{2} \mathrm{O}^{20}$ Sedangkan jamur Nigospora sp MA75, ketika dibiakkan pada 3 media yang berbeda menghasilkan senyawa yang berbeda pada masing-masing biakan. ${ }^{22}$

Senyawa metabolit sekuder yang diisolasi dari A. niger sampai tahun 2009 sudah mencapai 99 senyawa $^{23}$ diantaranya Malformin, Naphtho-r-pyrones, Aurasperone D, Nigerazine B, Nigragillin, Ochratoxin A dan Oxalic $\operatorname{acid}^{24}$ (Gambar 1). Salah satu senyawa yang memiliki aktivitas adalah malformin, yang dapat menghambat pertumbuhan Escherichia coli, Micrococcus luteus, Staphylococcus aureus, dan Proteus mirabilis. ${ }^{23}$

Tujuan dari penelitian ini adalah untuk mengisolasi senyawa metabolit sekunder yang dihasilkan $A$. niger pada media yang diperkaya sarang ratu termite dan untuk mengetahui aktivitas antibiotik senyawa hasil isolasi.

\section{Metode}

\subsection{Alat}

Laminar Air Flow (Biobase $^{\circledR}$ BBSV800), Autoklaf (All American ${ }^{\circledR}$ ), Magnetic stirer, Stirer $\left(\right.$ Iwaki $^{\circledR}$ Stirer BS46), Rotary evaporator (Buchi ${ }^{\circledR}$ Rotapor R-124), Labu rotary, Pipet mikro (Bench Mate $^{\circledR}$ Digital micro pipette), Vortex (Iwaki ${ }^{\circledR}$ Mixer TM 151), Timbangan (Mettler ${ }^{\circledR}$ PM200), Lemari pengering (oven) $\left(\operatorname{Kirin}^{\circledR}\right)$, Kolom kromatografi, Bejana Kromatografi 
Lapis Tipis (KLT), Plat KLT GF254 nm, Lampu UV254nm, Jarum Ose, Cawan Petri (Diameter $=10 \mathrm{~cm}$ ).

\subsection{Bahan}

Isolat jamur $A$. niger yang hidup pada sarang ratu termite $M$. gilvus Hagen., sarang ratu termite M. gilvus Hagen., Saboraud Dextrose Agar (SDA) $\left(\right.$ Merck $\left.^{\circledR}\right)$, Nutrient Agar (NA) $\left(\right.$ Merck $\left.^{\circledR}\right)$, Metanol, Aquadest, Etanol 70\%, Etil asetat, Kloroform, Natrium sulfat anhidrat, Dimetil sulfoksida (DMSO), Pereaksi $\mathrm{FeCl}_{3}$, Vanilin asam sulfat, Dragendorff, Silika gel P $60(0,063-0,200$ $\mathrm{mm}$, catt 1.07734.1000 $\mathrm{Merck}^{\circledR}$ ), Silika 60 $\mathrm{PF}_{254}$ tebal $1 \mathrm{~mm}$ (catt. 1.07747.100 Merck), $\mathrm{NaCl}$ fisiologis, Kloramfenikol, 2 bakteri uji (E. faecalis ATCC 29212, P. aeruginosa ATCC 27853).

\subsection{Prosedur Percobaan}

\subsubsection{Penyiapan Sampel Sarang Ratu dan} Pembuatan Media

Sampel sarang ratu termite $M$. gilvus Hagen., diambil di perkebunan sawit daerah Teluk Kuantan, Riau. Sarang ratu termite digerus hingga halus, lalu ditimbang dengan beberapa berat yang berbeda diantaranya 0,$25 ; 0,75$ dan $1 \mathrm{~g} / \mathrm{mL}$ media. Media dibuat dengan melarutkan $65 \mathrm{~g}$ serbuk SDA dalam 1 Liter aquadest dan dipanaskan sambil diaduk sampai terbentuk larutan yang jernih, kemudian ditambah perlahan serbuk sarang ratu termite aduk lagi sampai homogen sebelum disterilisasi.

\subsubsection{Pembiakan Jamur}

Isolat jamur $A$. niger dibiakkan dengan cara menggoreskan satu Ose isolat yang diambil dari stok murni pada permukaan media yang diperkaya dalam cawan Petri, lalu diinkubasi pada suhu kamar selama tiga minggu sampai pertumbuhan maksimal ditandai dengan permukaan petri dish sudah dipenuhi oleh spora.

\subsubsection{Metode Isolasi}

Jamur diektraksi dengan cara memasukkan pelarut metanol ke dalam cawan petri, diaduk perlahan supaya medium agar tidak terbawa, kemudian dipindahkan ke dalam wadah maserasi (botol). Jamur dimaserasi dengan metanol masing-masing 1,5 L selama 3 hari dan kemudian disaring. Gabungan maserat metanol diuapkan secara in-vacuo sehingga didapatkan ekstrak kental. Ekstrak kental kemudian difraksinasi dengan etil asetat menggunakan corong pisah, kemudian diuapkan secara in-vacuo sehingga diperoleh fraksi kental etil 1,360 gram dan fraksi kental sisa 0,915 gram. Masingmasing fraksi selanjutnya diuji aktivitas antibiotiknya.

Fraksi etil asetat dikromatografi kolom dengan silika gel 60 dengan fase gerak kombinasi n-heksan, etil asetat dan metanol dengan peningkatan kepolaran Step Gradient Polarity (SGP) sehingga diperoleh beberapa sub-fraksi, dan satu senyawa murni EG-1331-2 (20 mg, 1,47\%). Sub-fraksi (EG-13-3122) dikromatografi lapis tipis preparatif silika gel $60 \mathrm{PF}_{254}$ didapatkan senyawa murni EG13-34-9 (5 mg, 0,306\%).

Fraksi sisa dikromatografi kolom dengan silika gel 60 dengan fase gerak kombinasi butanol, butanol jenuh air dan metanol dengan peningkatan kepolaran Step Gradient Polarity (SGP) sehingga diperoleh beberapa sub-fraksi. Sub-fraksi (EG-13-43-1) dikromatografi lapis tipis preparatif dengan silika gel $60 \mathrm{PF}_{254}$ dan didapatkan senyawa EG-13-44-2 (33 mg, 3.60\%).

\subsubsection{Uji Aktivitas Antibiotik}

Uji aktivitas dilakukan dengan metode difusi agar terhadap dua bakteri uji $P$. aeruginosa ATCC 27853 dan E. faecalis ATCC 10541. Media Nutrien Agar sebanyak $20 \mathrm{~g} / \mathrm{L}$ digunakan untuk medium pembiakan bakteri. Kedua bakteri sebelum diinokulasi dalam media NA, disuspensikan dalam $\mathrm{NaCl}$ 0,9\%. Kekeruhan suspensi dalam $\mathrm{NaCl}$ $0,9 \%$ untuk bakteri diukur pada serapan $\lambda 580 \mathrm{~nm}, \mathrm{~T}=25 \%{ }^{24}$. Masing-masing sampel konsentrasi 200, $100 \mathrm{dan} 50 \mu \mathrm{g} / 10 \mu \mathrm{l}$, dipipet dengan micro syring pada kertas cakram dan diletakkan pada media agar dalam cawan petri yang sudah mengandung bakteri uji, diinkubasi pada $37^{\circ} \mathrm{C}$ dan diukur zona hambatnya setelah 24 jam. 


\section{Hasil}

Secara visual terlihat bahwa pada media yang diperkaya dengan $1 \mathrm{~g} / \mathrm{mL}$ sarang memberikan pertumbuhan yang palig baik, karena menghasilkan spora yang paling banyak (Gambar 2).

Hasil pemantauan senyawa metabolit sekunder ekstrak metanol jamur terlihat bahwa beberapa senyawa metabolit sekunder jamur yang tidak terbentuk ketika ditumbuhkan pada media SDA saja, kembali terbentuk ketika media tumbuhnya diperkaya dengan sarang ratu termite dan memiliki pola noda yang sama dengan ekstrak peneliti sebelumnya (Gambar 3).

Hasil kultivasi jamur $A$. niger sebanyak 50 Petri diperoleh ekstrak kental metanol sebanyak 2,285 gram (23,083\%), 1,360 gram $(59,518 \%)$ fraksi kental etil asetat dan 0,915 gram $(40,043 \%)$ fraksi kental sisa.

Hasil pemisahan dan pemurnian terhadap fraksi etil asetat dengan kromatografi kolom didapat senyawa murni EG-1331-2 seberat $20 \mathrm{mg}(1,47 \%)$ dan dengan kromatografi lapis tipis preparatif senyawa EG-13-34-9 seberat $5 \mathrm{mg}(0,306 \%)$.
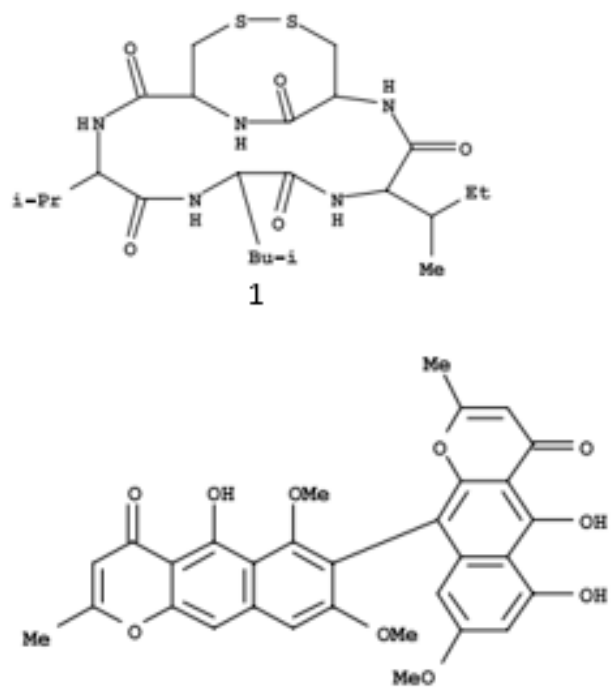

3
Hasil pemisahan dan pemurnian terhadap fraksi sisa dengan kromatografi kolom dan kromatografi lapis tipis preparatif didapat senyawa EG-13-44-2 seberat $33 \mathrm{mg}$ $(3,60 \%)$

Masing- masing senyawa dipertegas kemurniannya dengan metode Multiple Developing System (MDS), yang tetap menunjukkan pola KLT satu noda meskipun dilakukan KLT berulang pada satu plat tersebut. ${ }^{16,26}$

Hasil identifikasi dan karakterisasi dengan spektrum UV-visibel, senyawa EG13-31-2 memberikan serapan maksimum pada panjang gelombang $223,40 \mathrm{~nm}$, senyawa EG-13-34-9 pada panjang gelombang 272,00 nm, serta senyawa EG-13-44-2 pada panjang gelombang 262,20 $\mathrm{nm}$ (Tabel 1).

\section{Pembahasan}

Pada penelitian ini dilakukan isolasi dan uji aktivitas dari metabolit sekunder jamur $A$. niger. Jamur dibiakkan pada media yang diperkaya dengan sarang ratu termite $M$. gilvus Hagen. Tujuan media diperkaya adalah untuk mengkondisikan jamur agar
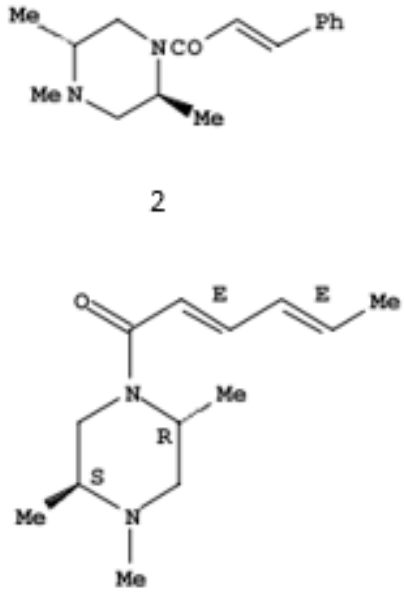

4<smiles>C[C@H]1Cc2c(Cl)cc(C(=O)N[C@@H](Cc3ccccc3)C(=O)O)c(O)c2C(=O)O1</smiles>

5

Gambar 1. Metabolite sekunder A.niger (1) Malformin, (2) Nigerazine B, (3) Aurasperone D, (4) Nigragillin, (5) Ochratoxin A24. 


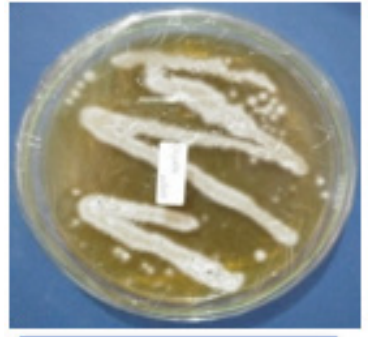

$0 \mathrm{~g} / \mathrm{mL}$

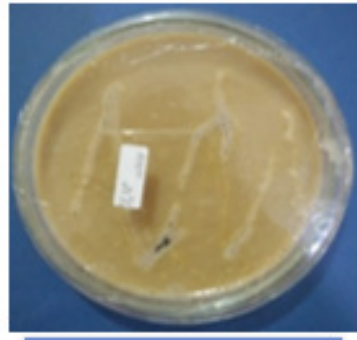

$0,25 \mathrm{~g} / \mathrm{mL}$

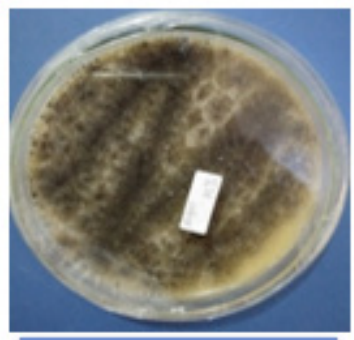

$0,75 \mathrm{~g} / \mathrm{mL}$

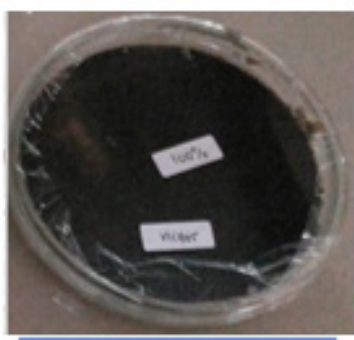

$1 \mathrm{~g} / \mathrm{mL}$

Gambar 2. Profil pertumbuhan isolat jamur Apergillus niger pada media Saboraud Dextrose Agar dengan berbagai penambahan sarang.

dapat tumbuh pada media yang menyerupai habitat aslinya. Karena pada dasarnya jamur dapat mengalami perubahan ketika habitatnya berubah. $^{20}$

Penelitian dimulai dengan menentukan konsentrasi sarang yang paling cocok untuk digunakan. Media diperkaya dengan tiga konsentrasi sarang yaitu 0,25; 0,74 dan $1 \mathrm{~g} /$ $\mathrm{mL}$ media. Hasilnya menunjukkan bahwa penambahan $1 \mathrm{~g} / \mathrm{mL}$ media memberikan pertumbuhan yang paling baik dibandingkan dengan konsentrasi lainnya. Terlihat dari jumlah spora yang dihasilkannya lebih banyak dan memenuhi permukaan cawan petri (Gambar 2). Hal ini dikarenakan semakin banyak sarang ratu yang ditambahkan maka unsur hara atau nutrisi yang didapatkan jamur untuk pertumbuhannya juga semakin banyak, sehingga pertumbuhannya bagus, namun apabila media diperkaya dengan jumlah melebihi $1 \mathrm{~g} / \mathrm{mL}$ media mengalami keretakan. $^{27}$

Berdasarkan profil KLT, terlihat bahwa metabolit sekunder yang dihasilkan A. niger yang dibiakkan pada media yang diperkaya sama dengan senyawa ketika $A$. niger hidup dihabitatnya. Hal ini diduga karena habitat asli jamur ini (sarang ratu) memiliki komposisi yang dapat menunjang pembentukan metabolit sekunder jamur.

Sarang ratu termite mengandung protein , lemak, abu, $\mathrm{Ca}$ dan $\mathrm{P}^{7,8,9}$, selain itu juga terdapat beberapa metabolit sekunder berupa fenol dan terpenoid. ${ }^{28}$ Sementara media SDA hanya terdiri dari nutrisi untuk pertumbuhan jamur diantaranya mycological peptone $10 \mathrm{~g}$, glukose $40 \mathrm{~g}$ dan agar $15 \mathrm{~g}$ dan tidak memiliki kandungan lemak dan logam seperti

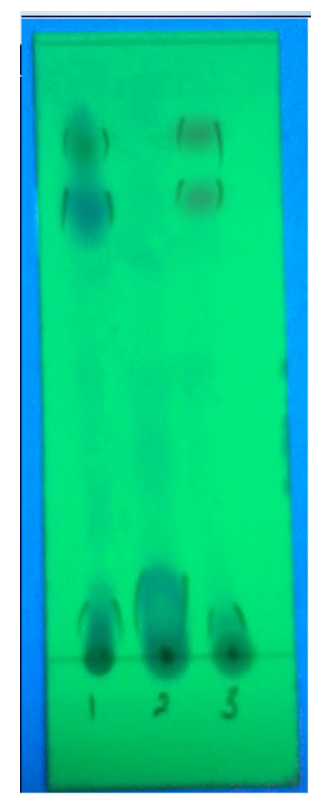

Gambar 3 Profil KLT ektrak metanol jamur A.niger dengan etil asetat : metanol (9,5:0,5) (1) Ekstrak metanol jamur pada media SDA yang diperkaya sarang $1 \mathrm{~g} / \mathrm{mL}$ media (2) Ekstrak metanol jamur pada media SDA saja (3) Ekstrak metanol jamur peneliti sebelumnya 


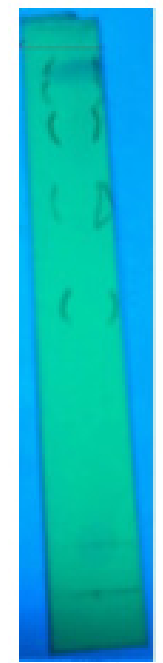

(a)

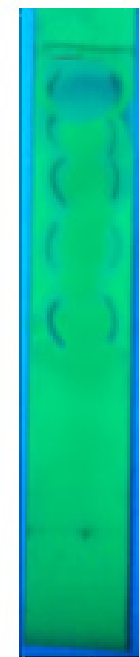

(b)

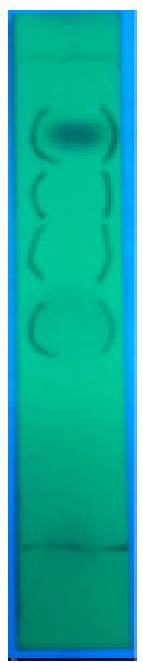

(c)

Gambar 4. Profil KLT hasil pemurnian dengan metode multiple developing system (MDS)(a) Senyawa EG-13-31-2 ( $\neg$ n-heksan: etil asetat (9,5:0,5) (b) Senyawa EG-13-34-9 (n-heksan: etil asetat $(3,5: 6,5)(c)$ Senyawa EG-13-44-2 (butanol jenuh air : metanol $(9,5: 0,5)$

pada sarang ratu. Sehingga ketika dilakukan kombinasi antara media SDA dengan sarang ratu memberikan pertumbuhan yang baik bagi Aspergillus niger.

Selanjutnya jamur dibiakkan sebanyak 50 petri. Jamur diinkubasi selama 3 minggu, karena jamur $A$. niger menghasilkan spora yang maksimum sampai 3 minggu. ${ }^{15}$ Kemudian jamur diekstraksi menggunakan metanol, Pemilihan metanol sebagai pelarut untuk maserasi karena metanol mempunyai kepolaran yang hampir sama dengan air sehingga dapat melarutkan senyawasenyawa yang bersifat polar tetapi juga dapat melarutkan senyawa yang non-polar.

Berdasarkan hasil uji aktivitas antibiotik terhadap ekstrak metanol, fraksi etil asetat dan fraksi sisa, diketahui bahwa kedua fraksi memiliki aktivitas terhadap kedua bakteri uji sehingga dilakukan isolasi terhadap kedua fraksi, yang selanjutnya juga dilakukan uji aktivitas. Metode ini disebut juga dengan istilah Bioassay fractination guided yaitu suatu metode untuk melihat keberadaan senyawa aktif suatu sampel, mulai dari ektrak, fraksi dan senyawa murni. ${ }^{29}$

Hasil pemisahan dan pemurnian fraksi etil asetat dengan kromatografi didapatkan senyawa EG-13-31-2 dan EG-13-34-9. Senyawa EG-13-31-2 (minyak kuning, 20 mg $(1,47 \%)$, sukar larut dalam n-heksan, larut baik dalam etil asetat dan metanol). Sementara senyawa EG-13-34-9 (amorf jingga, $5 \mathrm{mg}(0,306 \%)$, larut dalam metanol, sukar larut dalam etil asetat dan tidak larut dalam n-heksan).

Hasil pemisahan dan pemurnian fraksi sisa didapatkan senyawa EG-13-44-2 (amorf putih, $33 \mathrm{mg}(3,60 \%)$, larut dalam metanol dan butanol, dan tidak larut dalam etil asetat dan n-heksan). Senyawa ini merupakan senyawa polar, karena terdapat pada fraksi sisa dan

Tabel 1. Identifikasi dan Karakterisasi senyawa murni

\begin{tabular}{cccc}
\hline Notasi Senyawa & Bentuk & UV $\lambda_{\max }^{\text {MeOH }}$ nm, Abs & IR vmax cm-1 \\
\hline \multirow{2}{*}{ EG-13-1-2 } & & $735 ; 965 ; 1100 ; 1271 ;$ \\
& Minyak, kuning & $223,40(0,472)$ & $1375 ; 1456 ; 1730 ;$ \\
& & $1951 ; 2035 ; 2152 ;$ \\
EG-13-34-9 & Amorf, jingga & $249,60(0,206) ; 272,00$ & $1093 ; 12928 ; 3352$ \\
& & $(0,242)$ & $1948 ; 2092 ; 2592 ; 3258$ \\
EG-13-44-2 & Amorf, putih & $262,20(0,388)$ & $638 ; 788 ; 873 ; 1100 ;$ \\
& & & $1413 ; 1556 ; 2170 ; 3362$ \\
\hline
\end{tabular}


Tabel 2. Data diameter hambat senyawa murni terhadap kedua bakteri uji

\begin{tabular}{|c|c|c|c|c|c|c|}
\hline \multirow{3}{*}{$\begin{array}{c}\mathrm{K} \text { a d a r } \\
\text { senyawa } \\
(\mu \mathrm{g} / \text { disk })\end{array}$} & \multicolumn{6}{|c|}{ Diameter $(\mathrm{mm})$ zona hambat mikroba uji } \\
\hline & \multicolumn{3}{|c|}{ Enterococcus faecalis ATCC 29212} & \multicolumn{3}{|c|}{ Pseudomonas aeruginosa ATCC 27853} \\
\hline & EG-13-1-2 & EG-13-34-9 & EG-13-44-2 & EG-13-1-2 & EG-13-34-9 & EG-13-44-2 \\
\hline 200 & $8 \pm 1,0$ & $10 \pm 0,3$ & $8 \pm 0,6$ & $8 \pm 0,5$ & $9 \pm 0,6$ & $9 \pm 0,3$ \\
\hline 100 & $8 \pm 0,3$ & $7 \pm 0,3$ & - & $7 \pm 0,3$ & $7 \pm 0,5$ & $7 \pm 0,0$ \\
\hline 50 & $6 \pm 0,6$ & - & - & - & $6 \pm 0,0$ & $6 \pm 0,6$ \\
\hline
\end{tabular}

hanya larut dalam butanol dan metanol.

Berdasarkan reaksi kimia dengan vanillin asam sulfat senyawa EG-13-31-2 bewarna merah sementara senyawa EG13-31-2 dan EG-13-34-9 bewana ungu, menandakan ketiga senyawa ini positif terpenoid. Karena senyawa yang memiliki gugus isopren akan meberikan warna merahungu ketika direaksikan dengan vanillin dan asam sulfat ${ }^{29}$. Reaksi kimia dengan $\mathrm{FeCl} 3$ senyawa EG-13-34-9 memberikan warna biru kehitaman yang menandakan senyawa ini positif fenolik.

Pengujian aktivitas antibiotik dilakukan dengan metode difusi. Metode ini dipilih karena relatif lebih sederhana dan praktis dibandingkan dengan metode dilusi dan bioautografi serta hasil yang didapatkan cukup teliti untuk mengetahui adanya aktivitas antibiotik. Prinsip kerja dari metode difusi adalah mengamati adanya daerah bening di sekeliling cakram yang menunjukkan bahwa sampel mempunyai aktivitas menghambat pertumbuhan bakteri. ${ }^{30}$

Zona bening ini dihasilkan karena adanya aktivitas antibiotik dari senyawa yang terdapat pada cakram, senyawa aktif tersebut akan berdifusi ke media yang telah diinokulasi bakteri. Aktivitas antibiotik dikategorikan memiliki sensitifitas tinggi apabila diameter zona bening mencapai $>12 \mathrm{~mm}$, sedangkan sensitifitas sedang bila diameter zona bening sekitar 9-12 $\mathrm{mm}$, dan kategori sensitifitas rendah bila diameter berkisar antara 6-9 $\mathrm{mm}$ serta bila resisten apabila $6 \mathrm{~mm}$ (tidak memiliki zona hambat). ${ }^{31}$

$$
\text { Pada metode ini digunakan }
$$
kloramfenikol $1 \mathrm{mg} / \mathrm{mL}$ sebagai kontrol positif dan DMSO sebagai kontrol negatif.

Ketiga senyawa bersifat bakteriostatik, karena hanya dapat menghambat pertumbuhan bakteri tidak membunuhnya. Hal ini terlihat dari zona bening sekeliling cakram, setelah lebih dari 24 jam tidak ada lagi zona bening.

Berdasarkan pita serapan maksimum yang diperoleh dari spektrum

UV terindikasi adanya ikatan rangkap berkonyugasi, karena sistem konyugasi menyerap cahaya pada panjang gelombang diatas $200 \mathrm{~nm}$ dan manandakan adanya kromofor yang memberikan transisi dari $\pi$ ke $\pi^{*} 32$.

Pemeriksaan spektrum inframerah senyawa EG-13-31-2 menunjukkan ada ikatan C-O pada $968,78 \mathrm{~cm}^{-1}$, C-C pada $1100,66 \mathrm{~cm}^{-1}, \mathrm{C}=\mathrm{C}$ alifatik pada 1730,50 $\mathrm{cm}^{-1}$ dan C-H pada $2928,13 \mathrm{~cm}^{-1}$. Senyawa EG-13-34-9 memiliki ikatan C-O 1093,49 $\mathrm{cm}^{-1}, \mathrm{C}=\mathrm{C}$ aromatik pada $1587,00 \mathrm{~cm}^{-1}$ dan gugus $\mathrm{O}-\mathrm{H}$ pada $3258,68 \mathrm{~cm}^{-1}$. Senyawa EG13-44-2 memiliki ikatan C-O dan C-C pada $873,90 \mathrm{~cm}^{-1}$ dan ikatan $\mathrm{C}=\mathrm{C}$ pada 1556,41 $\mathrm{cm}^{-1}$. Pemeriksaan spektrum inframerah ini bertujuan untuk mengetahui absorbansi ikatan yang khas dan spesifik dari gugus fungsi senyawa organik dengan membandingkan daerah sidik jarinya. ${ }^{33}$

\section{Kesimpulan}

Pengayaan sarang $1 \mathrm{~g} / \mathrm{mL}$ media pada SDA memberikan pengaruh terhadap pertumbuhan dan metabolit sekunder dari Aspergillus niger in-habiting sarang ratu termite.

Dalam penelitian ini didapatkan tiga senyawa murni yaitu EG-13-31-2, EG-1334-9, EG-13-44-2.

Berdasarkan hasil reaksi kimia senyawa dengan vanillin asam sulfat, data spektrum uv-vis dan data inframerah ketiga senyawa adalah terpenoid dan hasil reaksi kimia senyawa EG-13-34-9 dengan $\mathrm{FeCl}_{3}$, data 
hasil spektrum uv-vis dan data inframerah, senyawa EG-13-34-9 adalah fenolik.

Masing-masing senyawa hasil isolasi memiliki daya hambat terhadap kedua bakteri uji (Pseudomonas aeruginosa ATCC 27853 dan Enterococcus faecalis ATCC 29212) dalam kategori bakteriostatik.

\section{Daftar Pustaka}

1. Alen Y. Ratu Termite Macrotermes gilvus Hagen., Kajian Awal Saintifik Dalam Pandangan Farmasi. Abstrak Seminar Nasional dan Workshop Perkembangan Terkini Sains Farmasi dan Klinik 6: 23 24 September 2016: Padang, Indonesia. 2016 a.

2. Subekti N, Duryadi D, Nandika D, Surjokusumo S, Anwar S. Distribution and Morphology Characteristic of Macrotermes gilvus Hagen., in The Natural Habitat. J Ilmu dan Tek Hasil. 2008;1(1): 27-33.

3. Robert OE, Frank UO, Agbonsalo OU. Influence of Ativities of Termites on Some Physical and Chemical Properties of Soil under Different Land Use Ptterns: A riview. Int J.Soil. Sci. 2007; ISSN:18164978..

4. Alen Y, Indraini RA. dan Yuliandra Y. Toksisitas Akut dan Sub - akut Freeze Drying Ratu Anai - anai ( Macrotermes gilvus Hagen.) terhadap fungsi hati mencit. Abstrak Seminar Nasional dan Workshop Perkembangan Terkini Sains Farmasi dan Klinik 6; 23 - 24 September 2016; Padang, Indonesia. 2016b.

5. Alen Y, Putri D, Damris M, Putri SFR, Dwithania M dan Suharti N. Uji Antibakteri Freeze Drying Ratu Rayap Macrotermes gilvus Hagen. Abstrak Seminar Nasional POKJANAS TOI ke52; 12-13 April 2017; Riau, Indonesia. Indonesia: STIFAR RIAU; 2017a.

6. Alen Y, Damris M, Putri dan Almahdy. Kajian Praklinik Serta Potensi Freeze Drying Ratu Rayap Macrotermes gilvus Hagen., Sebagai Kandidat Obat Herbal Dalam Sediaan Kapsul. Abstrak Seminar Nasional POKJANAS TOI ke-52; 12-13 April 2017; Riau, Indonesia. Indonesia:
STIFAR RIAU; $2017 \mathrm{~b}$.

7. Alen Y, Suarmin O, Suci LN, Kurniawan R, Yasardi F dan Ramadhani V. Analysis Levels of Fatty Acids from Freezedried Termite Queen Macrotermes gilvus Hagen., using GC-MS and Antihyperlipidemia Test. Abstract Paper of The Conference on Advancing the Life Science and Public Health Awrence; 10 11 July; Nagoya, Japan. 2016c.

8. Alen Y, Suci LN, Suarmin O, Suparman A, Larrasati A, Yeni YF dan Febriyenti. Isolasi (Penetapan Kadar) Metabolit Primer Ratu Anai-Anai (Macrotermes gilvus) Hagen., dan Potensi sebagai Obat Luka Bakar. Abstrak Paper dan Prosiding Seminar Nasional \& Workshop Perkembangan Terkini Sains Farmasi dan Klinik V; 6-7 November 2015; Padang, Indonesia. 2015a.

9. Alen Y, Suci LN, Suarmin O dan Rivai H. Analisis of Amino Acid Levels of Freeze Dried Termite Queen Macrotermes gilvus Hagen. Int $J$ of ind Herb and drug. 2017c;2(3):1-5.

10. Alamu OT, Amao AO, Nwokedo CI, Oke OA and Lawa IO. Diversity and Nutritional Status of Edible Insects in Nigeria: A Review. Int J. Biod and Conver. 2013;5(4): 215-222.

11. Korb, J. Termite Mound Architecture, from Function to Construction in Biol $\neg$ ogy of Termites: A Modern Synthesis. London: Springer Dordrecht Heidel $\neg$ berg. 349374pp; 2011.

12. Sujada N, Sungthong R and Lumyong S. Termite Nest as an Abundant Source of Cultivable Actinobacteria for Biotechnological Purposes. Microbes Environ. 2014; 29(2).

13. Mathew GM, Ju YM, Lai CY, Mathew DC and Huang CC. Microbial Community Analysis in The Termite Gut and Fungus Comb of Odontotermes formosanus: The Implication of Bacillus as Mutualists. FEMS Microbiol Ecol. 2012;79: 504-517.

14. Wójcik A and B Andres. Mildew Fungi Found in Termites (Reticulitermes lucifugus) and Their Nests. J Ento and Acaro Res. 2016;47: 2184. 
15. Alen Y, Sari MP dan Putra DP. Penapisan Jamur dari Sarang Anai-Anai (Macrotermes gilvus Hagen.) dan Uji Aktivitas Anti-Jamur. Abstrak Paper dan Prosiding Seminar Nasional \& Workshop Perkembangan Terkini Sains Farmasi dan Klinik V; 6-7 November 2015; Padang, Indonesia. 2015b.

16. Alen Y, Melati A dan Djamaan A. Isolasi Senyawa Antibiotika Jamur Aspergilus niger Simbiotik Sarang Ratu Anai- anai Macrotermes gilvus Hagen. Abstrak Seminar Nasional dan Workshop Perkembangan Terkini Sains Farmasi dan Klinik 6: 23 - 24 September 2016: Padang, Indonesia. 2016d.

17. Alen Y, Sarina G dan Djamaan A. Isolasi Senyawa Mayor Metabolit Sekunder Jamur Aspergilus flavus Simbiotik Sarang Ratu Anai - Anai ( Macrotermes gilvus Hagen.). Abstrak Seminar Nasional dan Workshop Perkembangan Terkini Sains Farmasi dan Klinik 6: 23 - 24 September 2016: Padang, Indonesia. 2016e.

18. Alen Y, Amelia R, Rahmi OAdan Djamaan A. Profil Klt Fraksi Etil Asetat Metabolit Sekunder Isolat Jamur Aspergillus flavus Dengan Penambahan Tanah Sarang Ratu Termite Macrotermes gilvus HAGEN., Pada Media SDA. Abstrak Seminar Nasional POKJANAS TOI ke-52; 12-13 April 2017; Riau, Indonesia. Indonesia: STIFAR RIAU; 2017d.

19. Alen Y, Guslianti E dan Suharti N. Uji Aktivitas Fraksi Etilasetate Ektrak Metanol Aspergilus niger, Simbiotik Sarang Ratu Termite Macrotermes gilvus Hagen., dengan Pengayaan Media SDA. Abstrak Seminar Nasional POKJANAS TOI ke-52; 12-13 April 2017; Riau, Indonesia. Indonesia: STIFAR RIAU; 2017 e.

20. Bode HB, Bethe B, Hofs R and Zeeck A. Big Effects from Small Change: Possible Ways to Explore Nature's Chemical Diversity. ChemBioChem; 2002

21. Wei H, Li Z, Li D, Gu Q and T Zhu. 2010. OSMAC (one strain many compounds) approach in the research of microbial metabolites--a review. Wei Sheng $\mathrm{Wu}$
Xue Bao. 2010;50 (6).

22. Shang Z, Li XM, Li CS and Wang BG. Diverse Secondary Metabolite Produced by Marine-Derived Fungus Nigrospora sp. MA75 on Various Culture Media. Chemistry \& Biodiversity; 2012.

23. Nielsen KG, Mogensen JMM, Johansen TO, Larsen and Frisvad JC. Review of Secondary Metabolites and Mycotoxins from Aspergillus niger group. Anal Bioanal Chem. 2009;395:1225-1242.

24. Blumethal C Z. Produktion of Toxic Metabolites in Aspergillus niger, Aspergillus oryzae, and Trichoderma reesei: Justification of Micotoxi Testing in Food Grade Enzyme Preparations Derived From the Tree Fungi. Regulatory Toxicology and Pharmacology. 2004;39:214-228.

25. Elidahanum H, Mardella S, Deddi PP. Studi aktifitas Antimikroba Ekstrak Akar Calophyllum soulatrii Burm.F. J Mat dan Peng Alam. 2004; 13(2): 95-99.

26. Handayani D, Handayani C, Krisyanella. Isolasi Senyawa Kimia Utama dari Fraksi Aktif Sitotoksik Spon Laut Petrosia sp (MN05). J Far. Higea. 2012; 4(1):24-30.

27. Alen Y, Amelia R, Djamaan A. Profil KLT dan Uji Aktivitas Metabolit Sekunder Aspergillus flavus "In-Habiting" Sarang Ratu Termite Macrotermes gilvus pada Media Diperkaya. Ind J of Phar Sci and Tech. 2018; 5(1):31-42.

28. Alen Y, Afnillia F, Rustini. 2017c. Uji Antibakteri Metabolit Sekunder Ekstrak Metanol sarang Ratu Termite Macrotermes gilvus Hagen. Abstrak Seminar Nasional POKJANAS TOI ke52; 12-13 April 2017; Riau, Indonesia. Indonesia: STIFAR RIAU; $2017 \mathrm{f}$.

29. Syafiudin A. Senyawa Alam Metabolit Sekunder. Yogyakarta: The Publish Publisher; 2014

30. Hudzicki J. Kirby-Bauer Disk Diffusion Suspectibility Test Protocol. American Society For Microbiology; 2009.

31. Arora DS and Bhardwaj. Antibacterial Activity of Some Medicinal Plants. Geo. Bios.1997;(24):127-131.

32. Gandjar I, Abdul G. Analisis obat secara 
spektrofotometri dan kromatografi.

Yogyakarta: Pustaka Pelajar; 2013

33. Dachriyanus D.Analisis Struktur Senyawa

Organik Secara Spektrofotometri.

Padang: Andalas University Press; 2004 